\title{
ECTOPIC DECIDUAL REACTION IN BLADDER
}

Blessing Dhliwayo ${ }^{1}$ and Ananda Kumar Dhanasekaran ${ }^{2}$

${ }^{1}$ Royal Preston Hospital, Preston, Lancashire, United Kingdom

${ }^{2}$ City Hospital, Dudley Road, Dudley Road, Birmingham, United Kingdom.

Corresponding Author Ananda Kumar Dhanasekaran: managestones@gmail.com

Submitted: October 23, 2018. Accepted: November 19, 2018. Published: January 24, 2019.

\section{CASE PRESENTATION}

A 32-year-old teacher, 12-weeks' pregnant presented with visible hematuria to midwife-led clinics. Ultrasound scans showed a single viable fetus and irregular lesion at the left side of the bladder. It measured $28 \times 26 \times 34 \mathrm{~mm}$ with presence of internal Doppler vascularity raising high suspicion of urological cancer. Ultrasound Doppler longitudinal with cross section images are shown in Figures 1 and 2. Both the kidneys

FIG. 1 Ultrasound Doppler.

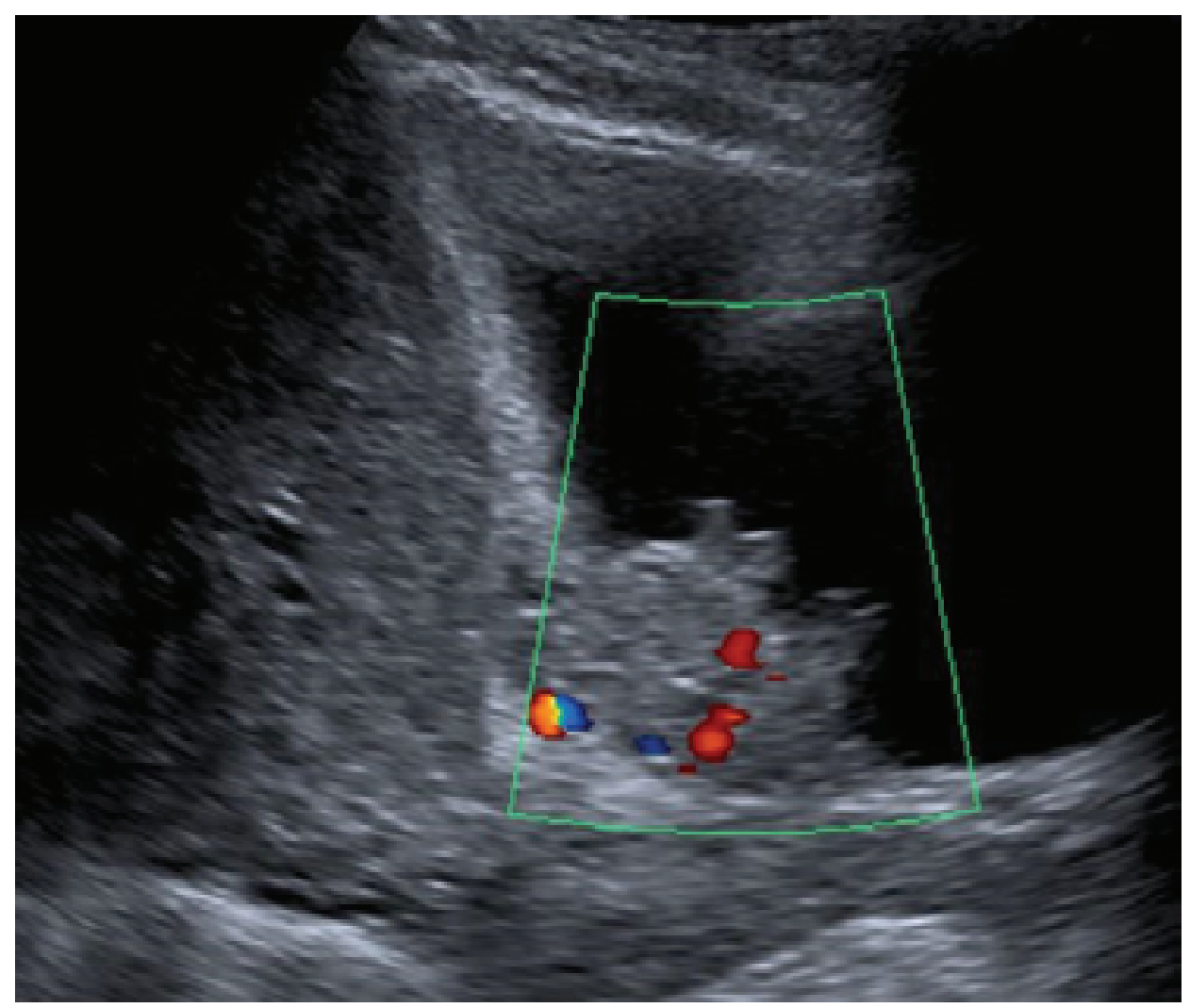

J Endolum Endourol Vol 1(2):e13-e16; January 24, 2018.

This article is distributed under the terms of the Creative Commons Attribution-Non Commercial 4.0 International License. (C) 2018 Dhliwayo and Dhanasekaran. 
FIG. 2 Ultrasound Doppler.

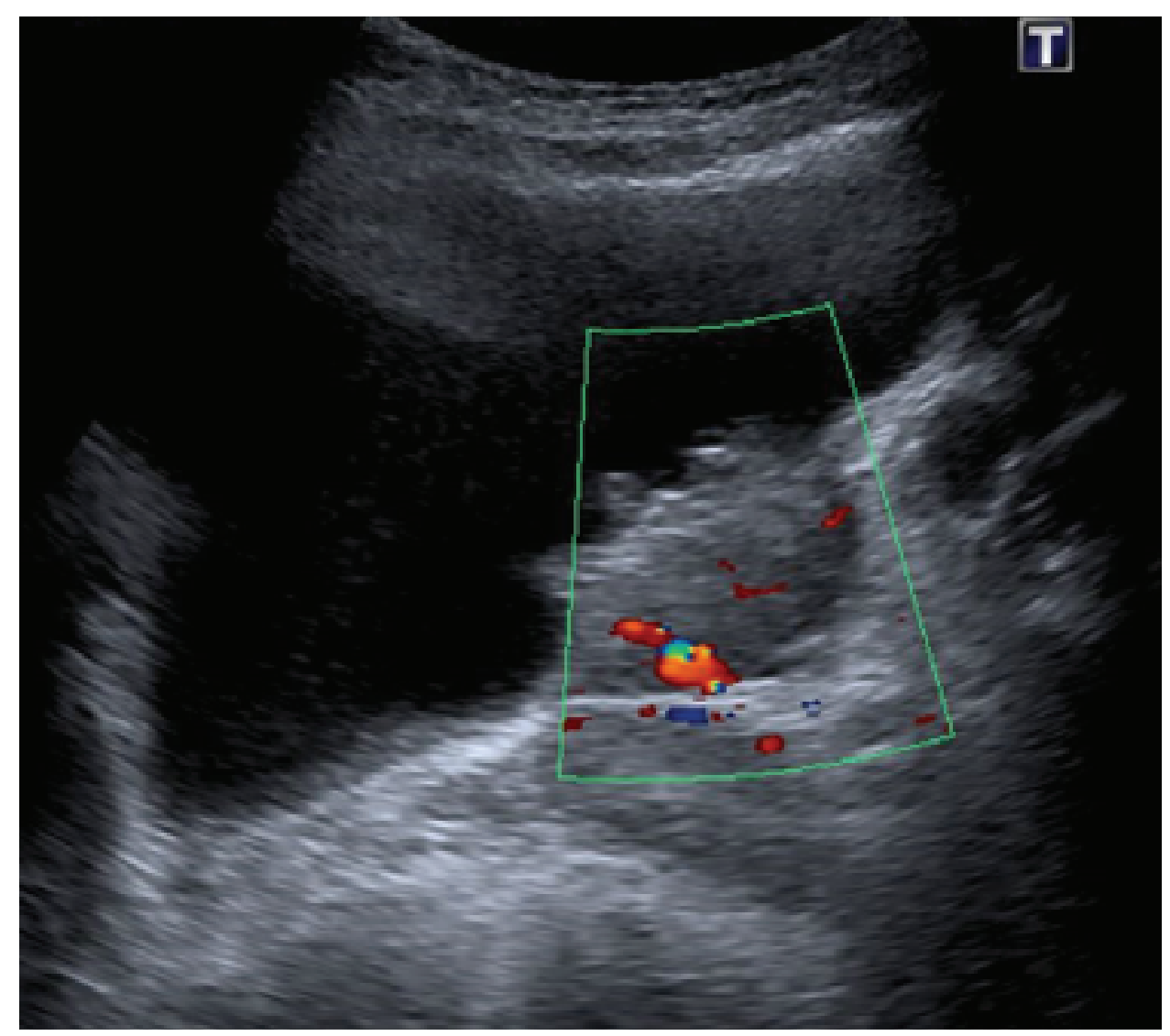

were normal. She was referred to urology. Her flexible cystoscopy showed irregular lesion covering left ureteric orifice coinciding with the ultrasound findings (Figure 3). Urine microscopy has no signs of infection. Urine cytology has no malignant cells. Findings were discussed in Urology Multidisciplinary Meeting. Considering the nature of the lesion transurethral resection of bladder lesion was planned.

\section{DIAGNOSTIC CONUNDRUM}

Informed consent obtained. Antenatal team involved to help in pregnancy related support. Under spinal anesthesia transurethral resection of bladder lesion done. Both the ureteric orifices were normal. She had uneventful recovery and sent home in 24 hours. Bladder fragments histology showed normal urothelium. Lamina propria contains nodular aggregates of decidual tissue with cells having abundant eosinophilic cytoplasm, vesicular nuclei and inconspicuous nucleoli. Some degenerative changes are also seen in some of the decidual cells. No endometrial tissue or chorionic villi are seen. Diagnosis of ectopic decidual reaction in bladder was made. Histology in $4 \times$ shown in Figure 4 and $20 \times$ shown in Figure 5. She was updated on the good news of benign histology. She has completed her pregnancy uneventfully.

\section{LITERATURE REVIEW AND DISCUSSION}

The decidual reaction is the set of changes in the endometrium of the uterus that prepare it for implantation of an embryo due to progesterone. These changes are observed in each menstrual cycle of female and enhanced after implantation. These changes include swelling of stromal cells due to accumulation of glycogen and other nutrients. Ectopic decidual reaction is well explained in literature in intraperitoneal locations 
FIG. 3 Flexible cystoscopy showed irregular lesion covering left ureteric orifice.

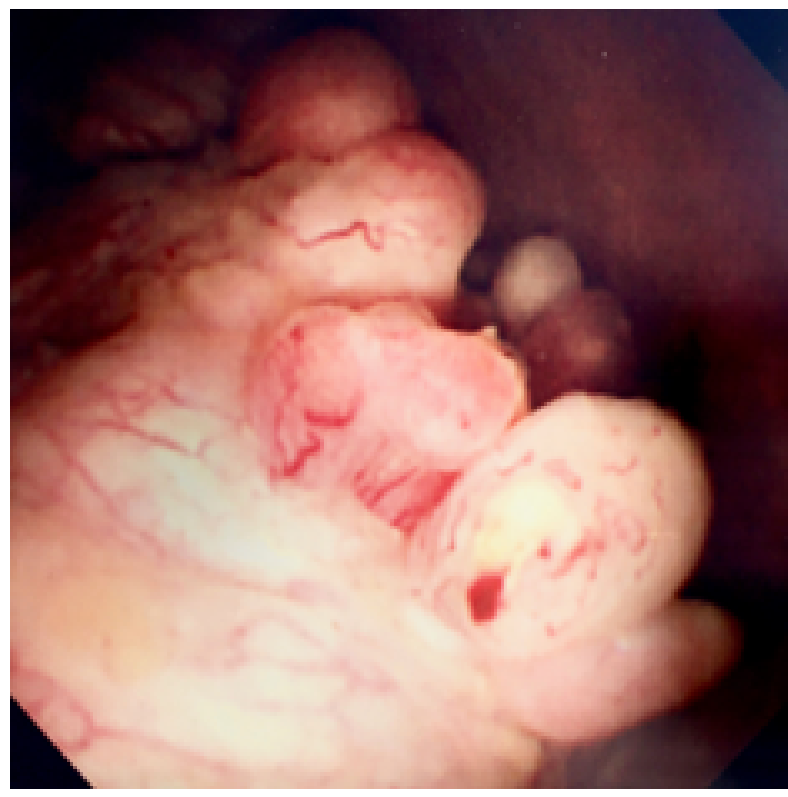

FIG. 4 Histology in $4 \times$.

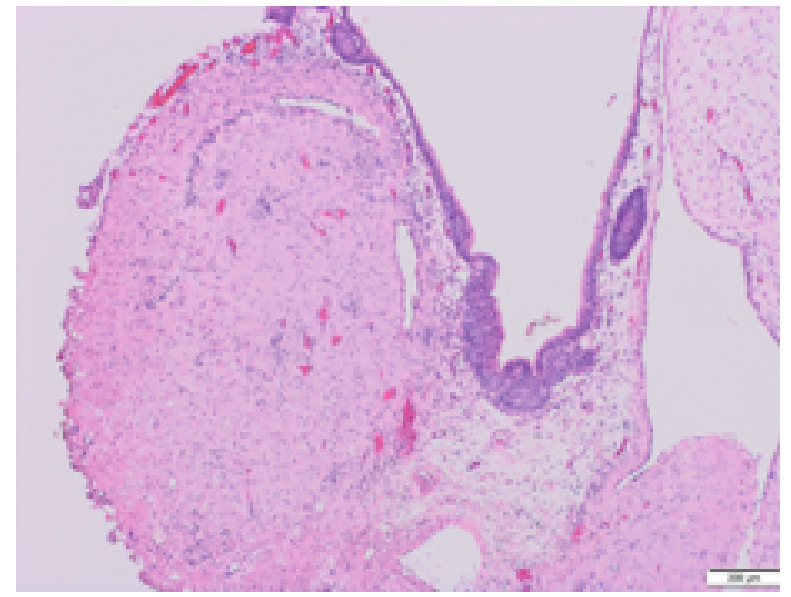

and genital tracts. But ectopic decidual reaction in bladder mimicking bladder growth is extremely rare. It is a difficult differential diagnosis because of its extreme rarity.

The first report of decidual transformation outside of the uterine mucosa was made by Walker in I887,
FIG. 5 Histology in $20 \times$.

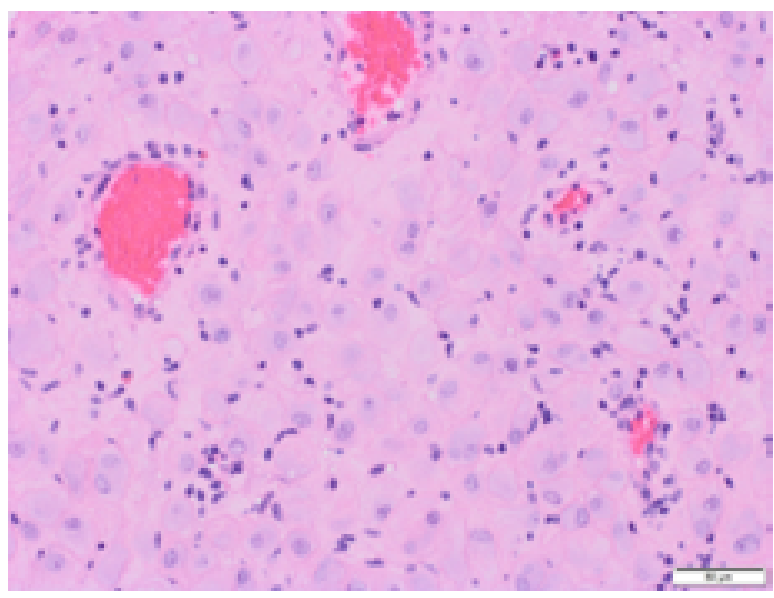

who observed it in association with an extra-uterine pregnancy. ${ }^{1}$ Taussig $^{2}$ coined the term ectopic decidua to describe the phenomenon in its extra-mucosal locations, and ectopic decidua has been noted in association with pregnancy in such diverse locations as the endocervical stroma, the sub-serosa of the corpus uteri and its ligamentous attachments, the endosalpinx, the serosal surfaces of the fallopian tubes, ovaries, omentum, vermiform appendix, small and large intestine, urinary bladder, and portions of the mesenteries. Meyer ${ }^{3}$ stressed the role of healed, low-grade, and pre-existing inflammation, especially that associated with the formation of adhesions, in the sensitization of the tissues for the decidual response. Ectopic decidua in pregnancy has been observed in the umbilicus, in laparotomy and hysterotomy scars, and in association with adenomyosis and endometriosis. Weller ${ }^{4}$ has pointed out that the regional distribution of the ectopic decidual response corresponds with the distribution of endometriosis. William B. Ober et al. ${ }^{5}$ published case series of 16 patients in 1957.

Only one case report was published in 2009 for bladder submucosal ectopic decidual reaction. ${ }^{6}$ In this case report we present florid papillomatos ectopic decidual reaction making difficult to differentiate from bladder transitional cell carcinoma. We hope this article will create awareness of this entity and help to treat similar patients in future. Since this bladder lesion resembles bladder cancer knowledge about ectopic 
decidual reaction in bladder will avoid unnecessary apprehension and interventions. The learning point in this case report is to be aware of rare differential diagnosis of ectopic decidual reaction in pregnancy in pregnant patients presenting with bladder lesions.

\section{REFERENCES}

1. Walker A. Der Bau der Eihdute bei Graviditas abdominalis. Virchows Arch. f. path. Anat 1887;107:72-99.

2. Taussig FJ. Ectopic decidua formation. Surg Gynec \& Obst I906;2:292-303.
3. Meyer R. Die Entziindung als Entstehungsursache ektopischer Decidua oder Paradecidua. Ztschr. f. Geburtsh. u. Gynaik. 1913;74:250-77.

4. Weller CV. The ectopic decidual reaction and its significance in endometriosis. Am J Path 1935;11:287-290.

5. Ober WB, Grady HG, Schoenbucher AK. Ectopic ovarian decidua without pregnancy. Am J Pathol 1957;33:199-217.

6. Szopiński TR, Sudok-Szopinska I, Dzik T, Borówka A. Ectopic decidual reaction in the urinary bladder presenting as a vesical tumor. Urology 2009;74:1232-33. 